ISSN: 1110-5623 (Print) - 2090-0570 (Online)

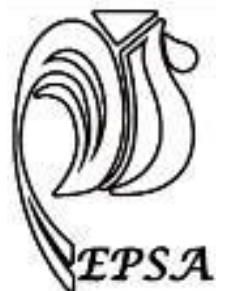

\title{
EFFECT OF DIETARY CHOLECALCIFEROL AND ANETHOLE SOURCE ON PRODUCTIVE AND REPRODUCTIVE PERFORMANCE OF LOCAL LAYING HENS 1-FROM 25 TO 40 WEEKS OF AGE
}

M.M. Beshara; Hoda A. El- Gabry; Kh.M. Attia and R.A. Hasan

Anim. Prod. Res. Instit., Agric. Res. Center, Minis. of Agric. Dokki, Giza. Corresponding author: Malak Mansour: E-mail: malakman88@ yahoo.com

Received: 19/ 08/2018 Accepted: 03 /11/2018

\begin{abstract}
A total number of 189 local Sinai laying hens (162 female + 27 males), 25weeks-old, were equally divided into nine dietary treatments to investigate the effect of dietary different sources of trans-anethol (anise seeds or oil) included three levels of trans-anethol ( 0 , $140 \mathrm{mg}$ trans/anethol from adding $4 \mathrm{~g}$ anise seeds and $140 \mathrm{mg}$ trans-anethole from adding $180 \mathrm{mg}$ anise oil $/ \mathrm{kg}$ diet) and three levels of cholecalciferol (vitamin $\mathrm{D}_{3}$ ) in $3 \times 3$ factorial design on productive and reproductive performance during the laying period (25-40 weeks of age). The dietary levels of trans-anethole and vitamin $\mathrm{D}_{3}$ included $3 \times 3$ factorial design $(0,4 \mathrm{~g}$ anise seeds and $180 \mathrm{mg}$ anise oil $/ \mathrm{kg}$ diet, each contained 2000, 2750 and $3500 \mathrm{IU}$ vitamin $\mathrm{D}_{3} / \mathrm{kg}$ diet). The results show that hens fed diet $180 \mathrm{mg}$ anise oil/ $\mathrm{kg}$ diet alone or with $3500 \mathrm{IU}$ vitamin $\mathrm{D}_{3} / \mathrm{kg}$ diet had the highest record of egg production and significantly exceeded basal diet and other treatments. Also, the high level of vitamin $\mathrm{D}_{3}(3500 \mathrm{IU} / \mathrm{kg}$ diet) produced significantly higher egg production than basal diet $(2000 \mathrm{IU} / \mathrm{kg}$ diet $)$. The best value of feed conversion was observed as a result of the diet with $180 \mathrm{mg}$ anise oil/ $\mathrm{kg}$ diet, $3500 \mathrm{IU}$ vitamin D3 and the interaction between the same treatments compared to the basal diet. Hatchability \% and chick weight at hatch significantly increased due to addition of $4 \mathrm{~g}$ anise seed $/ \mathrm{kg}$ diet compared to the basal diet. Moreover, addition of $2750 \mathrm{IU}$ vitamin $\mathrm{D}_{3} / \mathrm{kg}$ diet resulted in significantly higher hatchability of fertile eggs and chick weight at hatch than by basal diet. Calcium content in blood serum $(\mathrm{mg} / \mathrm{dl})$ significantly decreased for hens fed diet supplemented with $180 \mathrm{mg}$ anise oil/ $\mathrm{kg}$ diet compared to the basal diet. Interaction between $180 \mathrm{mg}$ anise oil and $3500 \mathrm{IU}$ vitamin $\mathrm{D}_{3} / \mathrm{kg}$ diet resulted in a significant increase in total protein of serum. A significant decreased was observed in egg shell calcium content and tibia phosphorus $(\mathrm{mg} / \mathrm{g}$ ) due to addition of $4 \mathrm{~g}$ anise seed and 180 anise oil/ $\mathrm{kg}$ diet compared to the control diet. In this respect, results revealed that the calcium content of egg shell was significantly decreased due to interactions between most dietary treatments. The results revealed an important role of adding $180 \mathrm{mg}$ anise oil $+3500 \mathrm{IU}$ vitamin $\mathrm{D}_{3} / \mathrm{kg}$ in Sinai laying hens diets for maximizing the productive performance and economic efficiency, and the addition of $4 \mathrm{~g}$ anise seed powder + 2750 or $3500 \mathrm{IU}$ vitamin $\mathrm{D}_{3}$ to maximize hatchability \% during the period $25-40$ weeks of age.
\end{abstract}

Key Words: Cholecalciferol - Anethole - Egg production - Fertility - Hatchability 
M.M. Beshara et al.

\section{INTRODUCTION}

Most herbs and spices contain various chemicals as part of their intercellular composition and these chemicals have the ability to help animals stay healthy when fed and may extend shelf life of animal products when treated with them (HeeJeong et al., 2001). Anise (Pimpinella anisum), a member of the Apiaceae family, is an annual aromatic plant. The part of the plant used, is the fruit, in particular the seed and its essential oil. Anise has been examined for its digestion stimulating properties (Cabuk et al., 2003), its antibacterial (Tabanca et al., 2003), antifungal (Soliman and Badea, 2002), and antioxidant (Gulcin et al., 2003). Soltan et al. (2008) mentioned that $0.5 \mathrm{~g}$ anise seed/kg die had stimulatory immune effect and may provide hepato protective effect. Anise oil could be considered as a potential natural growth promoter for poultry (Ciftci et al., 2005). Anise seed contain $2-6 \%$ of essential oil, phenolic, estragole and trans-anethole, which is a powerful phytoestrogen and the main compound of the oil 80-95\% (Christaki et al., 2012). In the adult bird oviduct function is maintained by estrogen together with progesterone and androgen (Etches, 1996). Phytoestrogens are estrogenic compounds in plants able to evoke biological responses by activating estrogen receptor $\alpha$ and estrogen receptor $\beta$ (Dusza et al., 2006). Phytoestrogens are high affinity ligands especially for estrogen receptor $\beta$, but the doses that are biologically active differ between species (Dusza et al., 2006).

Cholecaciferol (vitamin $\mathrm{D}_{3}$ ) is routinely added to layer's diet, as the availability of calcium depends on not only intestinal absorption from feed, but the skeleton also acts as a source of calcium during the dark hours of the day. Thus during eggshell synthesis, blood calcium is rapidly mobilized, thereby reducing its levels. According to NRC (1994), the requirement for egg-type white egg breeders of vitamin $\mathrm{D}_{3}$ is $300 \mathrm{IU}$ of vitamin D3/kg diet for a hen with a $100 \mathrm{~g}$ of feed intake per day. Suggested levels for broiler breeders in books and commercial guidelines vary from500 (Scott et al., 1982) to 3,500 (Ross Feeding Program Summary, 2000). Vitamin $D_{3}$ plays a critical role in the absorption of calcium to calcify bone (Fritts and Waldroup, 2003), in order for vitamin $\mathrm{D}_{3}$ to carry out its physiological functions which include calcium transport and cellular differentiation, it must undergo a two-step hydroxylation, first in the liver to produce 25hydroxycholecalciferol $\quad\left(25-\mathrm{OH}-\mathrm{D}_{3}\right)$, followed by a second hydroxylation in the kidneys to produce 1, 25- $(\mathrm{OH}) 2-\mathrm{D} 3$, the biologically active, hormonal form of vitamin $\mathrm{D}_{3}$ (DeLuca, 2004). Vitamin $\mathrm{D}_{3}$ involved in calcium and phosphorus absorption in the gut, bone mineralization (bone formation) and demineralization (bone mobilization), and calcium and phosphate reabsorption by the kidney (Combs, 1998). Also it plays an important role in the calcium metabolism of the laying hen (Fleming, 2004). Swiatkiewicz et al. (2017) reported that vitamin $D_{3}$ is important for immune response and muscle proliferation. Thus, the aim of this study was to invistigate the effect of anise seed or anise oil, vitamin $\mathrm{D}_{3}$ and their combination on productive and reproductive performance of Sinai 
Cholecalciferol - Anethole - Egg production - Fertility - Hatchability

laying hens during the period from 25 to 40 weeks of age.

\section{MATERIALS AND METHODS}

Bird's management and diets:

This study was conducted at El-Serw Poultry Research Station, Animal Production Research Institute, Agriculture Research Center, Egypt. One hundred and eighty nine Sinai fowls (162 females and 27 males) at 25 weeks of age were randomly assigned to nine treatments in an experiment lasted for 16 weeks. Birds were weighed and assigned to nine treatments of a $3 \times 3$ factorial arrangement included three levels of trans-anethole $(0,140 \mathrm{mg}$ trans/anethole $)$ from two sources (anise seed powder and anise oil) and 3 levels of vitamin $\mathrm{D}_{3}$ (basal diet contained $2000 \mathrm{IU} / \mathrm{kg}$ diet), 2750 and $3500 \mathrm{IU}$ vitamin $\mathrm{D}_{3} / \mathrm{kg}$ diet). Each treatment had three replicates (6 hens and 1 male/ replicate). During the experiment period, birds received 16 $\mathrm{h}$ /day of manipulated lighting. The experimental diets were as the following: The basal diet contain 2000 IU vitamin $\mathrm{D}_{3} / \mathrm{kg}$ diet and without adding transanethol and $\left(\mathrm{T}_{1}\right)$, the basal diet supplemented with $750 \mathrm{IU}$ vitamin $\mathrm{D}_{3} / \mathrm{kg}$ diet $\left(\mathrm{T}_{2}\right)$, the basal diet with $1500 \mathrm{IU}$ vitamin $\mathrm{D} 3 / \mathrm{kg}$ diet $\left(\mathrm{T}_{3}\right)$, the basal diet (contained $2000 \mathrm{IU}$ vitamin $\mathrm{D}_{3} / \mathrm{kg}$ diet) supplemented with $4 \mathrm{~g}$ anise seed powder/ $\mathrm{kg}$ diet $\left(\mathrm{T}_{4}\right)$, the basal diet supplemented with $4 \mathrm{~g}$ anise seed powder/ $\mathrm{kg}$ diet and supplemented with $750 \mathrm{IU}$ vitamin $\mathrm{D}_{3} / \mathrm{kg}$ $\operatorname{diet}\left(\mathrm{T}_{5}\right)$, the basal diet supplemented with $4 \mathrm{~g}$ anise seed powder/ $\mathrm{kg}$ diet and $1500 \mathrm{IU}$ vitamin $\mathrm{D}_{3} / \mathrm{kg} \operatorname{diet}\left(\mathrm{T}_{6}\right)$, the basal diet supplemented with $180 \mathrm{mg}$ anise oil / $\mathrm{kg}$ diet $\left(\mathrm{T}_{7}\right)$, the basal diet supplemented with $180 \mathrm{mg}$ anise oil/ $\mathrm{kg}$ diet and $750 \mathrm{IU}$ vitamin $\mathrm{D}_{3} / \mathrm{kg} \operatorname{diet}\left(\mathrm{T}_{8}\right)$, the basal diet supplemented with180 mg anise oil/ kg diet and $1500 \mathrm{IU}$ vitamin $\mathrm{D}_{3} / \mathrm{kg}$ diet ( $\left.\mathrm{T}_{9}\right)$.The birds fed a layer diet according to NRC 1994 recommend. Composition and calculated nutrients of experimental diets presented in Table 1.

Productive performance:

Feed intake of each replicate was recorded every 28 days. Body weight (BW) was weighed at the beginning and at the end of the experiment. Egg production, egg mass and feed conversion ratio as feed consumed (g) / egg mass (g) were also determined.

Reproductive traits:

Semen was collected during the experimental period, and then ejaculate volume, sperms motility and concentration were determined for each cock (Kammer et al., 1972). In addition, fertility, hatchability and chick weight at hatch were measured at the end of study.

\section{Slaughter test:}

At the end of experiment, after slaughter, blood samples were collected in clean tubes without anticoagulant, then the blood was centrifuged at $3500 \mathrm{ppm}$ for 15 minutes to separate the serum that used for determination of total protein, albumin, calcium and phosphorus. These biochemical measurements were performed calorimetrically by using commercial kits. In addition, the right tibia was removed and ashed to determined calcium $(\mathrm{Ca})$, and phosphorus (P). In addition, six eggs per treatment were collected and the shell egg ashed to determined $\mathrm{Ca}$ and $\mathrm{P}$ by using commercial kits. 
M.M. Beshara et al.

Economic efficiency:

Economic efficiency for egg production were expressed as hen-production and calculated using the following equation:

Economic efficiency $(\%)=($ Net return $\mathrm{LE} /$ Total feed cost LE) $\times 100$.

Statistical analysis:

Data were statistically analyzed using General Linear Models Procedure of the SPSS (2008), differences between treatments were subjected to Duncan's Multiple Range - test (Duncan, 1955).

The following model was used to study the effect of treatments on the parameters investigated as follows:

Yijk $=\mu+\mathrm{Ti}+\mathrm{Rj}+(\mathrm{TR}) \mathrm{ij}+$ ejik

Where :Yijk $=$ An observation; $\mu=$ overall mean ; $\mathrm{T}=$ effect of anethol level; $\mathrm{I}=(1,2$ and 3 ); $R=$ effect of vitamin $D_{3}$ level; $j=$ $(1,2$ and 3$) ; \mathrm{TR}=$ effect of interaction between anethol source and vitamin $\mathrm{D}_{3}$ level ; and ejik = Experimental error.

\section{RESULTS AND DISCUSSION}

Productive performance:

Results given in Table (2) illustrated that egg number/hen significantly improved due to the feeding on diet supplemented with $180 \mathrm{mg}$ anise oil/kg diet as compared to the diet without anethol source during the first, third and collective periods. Also, results indicated that adding $3500 \mathrm{IU}$ of Vitamin $\mathrm{D}_{3} \mathrm{~kg}$ diet resulted in a significant increase in egg number /hen than the diets supplemented with 2000 and $2750 \mathrm{IU} / \mathrm{kg}$ diet during the overall period. In addition, it could be concluded that irrespective of the fluctuations observed in egg number during the interval periods, hens fed diet with $180 \mathrm{mg}$ anise oil + $3500 \mathrm{IU}$ vitamin $\mathrm{D}_{3} / \mathrm{kg}$ diet produced the highest egg number as compared with the other treatments.

No significant differences were observed in average egg weight (g/egg) among the different treatments of trans-anethole source and basal diet (without adding anethol source) through all periods of the study with exception of the periods from 33 to 36 and from 37 to 40 weeks of age. Also, adding vitamin $\mathrm{D}_{3}$ had no significant influence on egg weight. On the other hand, the combination between anise seed powder and 2750 IU vitamin $\mathrm{D}_{3} / \mathrm{kg}$ diet led to significantly increase in egg weight during the third and fourth periods compared to the diet contained $2000 \mathrm{IU}$ vitamin $\mathrm{D}_{3} / \mathrm{kg}$ diet.

It is evident that egg mass (Table 3) almost followed the same trend of egg number as diet supplemented with 180 $\mathrm{mg}$ anise oil/ $\mathrm{kg}$ diet resulted in a insignificant increase in egg mass by about $6.29 \%$ compared to the diet without anethol source. No significant effect due to adding vitamin $\mathrm{D}_{3}$ on egg mass compared to the diet with 2000 IU vitamin $\mathrm{D}_{3} / \mathrm{kg}$ diet.

The results showed that no significant influence due to the dietary combination treatments on egg mass during the first and third period compared to the basal diet which contained 2000 IU of vitamin $\mathrm{D}_{3}$ and without adding anethol source. However, during the overall period, results showed that the diet supplemented with $180 \mathrm{mg}$ anise oil/ $\mathrm{kg}$ diet $+3500 \mathrm{IU}$ Vitamin $\mathrm{D}_{3}$ resulted in a significant improvement in egg mass compared to the basal and other dietary treatments except for the basal diet supplemented with 3500 IU Vitamin $\mathrm{D}_{3}$ and the diet supplemented with $180 \mathrm{mg}$ anise oil + 2750 IU Vitamin $\mathrm{D}_{3} / \mathrm{kg}$ diet. In general, results in the present study showed that egg production was better when the anise oil and the high level of vitamin $\mathrm{D}_{3}$ was added together than when it was used separately suggesting synergistic effect. 
Cholecalciferol - Anethole - Egg production - Fertility - Hatchability

Results in Table 4 clarified that there was no significant effect due to supplementation of anethol source, vitamin $\mathrm{D}_{3}$ and their combination on feed intake during the different interval periods except for the period from 25 to 28 weeks of age. Feed conversion ratio was more related to values of egg production than feed intake, therefore, the best value of feed conversion irrespective the fluctuations from period to another with no fixed trend was observed as a result of the diet with $180 \mathrm{mg}$ anise oil/ $\mathrm{kg}$ diet, $3500 \mathrm{IU}$ vitamin D3 and the interaction between the same treatments compared to the diet with 2000 IU vitamin $\mathrm{D}_{3}$ and free anethol.

The results in the current study clarified that the layer diet supplemented with 180 $\mathrm{mg}$ anise oil/ $\mathrm{kg}$ diet alone or with 3500 $\mathrm{IU}$ vitamin $\mathrm{D}_{3} / \mathrm{kg}$ diet occupies the first position regarding egg production and significantly exceeded the other treatments, then the diet supplemented with $3500 \mathrm{IU}$ vitamin $\mathrm{D}_{3} / \mathrm{kg}$ diet came second in this trait. This improvement may be due to anise oil contains $80-95 \%$ trans-anethol which is the main component of the oil and is a powerful phytoestrogen (Christaki et al., 2012). The estrogenic activities due to transanethole seem to be the most likely explantion for this effect; however, there are other beneficial properties of anise. According to Ertas et al. ( 2005) and AlShmmari (2011) who reported that anise oil enhance the digestion of protein, cellulose and fat, ileal digestibility of nutrients, increase the activities of pancreatic lipase and amylase as well as it have antioxidant activity. In addition, the beneficial impact of anise oil in layer diets can be explained by the fact that, anise have medical properties such as antimicrobial effect (Tabanca et al., 2003) and antifungal effect (Soliman and Badea, 2002) which improved the over all productive performance of laying hens. In contrast, Botsoglou et al. (2004) reported that addition of plant extracts or essential oils to the diet had no beneficial effect on feed conversion ratio.

Moreover, in the adult bird oviduct function is maintained by estrogen together with progesterone and androgen (Etches, 1996). This effect may be due to antioxidant and antimicrobial activity of extract anise seeds (Gulcin et al., 2003). Also this estrogenic activity may be the main reason for improve laying performance. This is in consistent with Zhao et al. (2005) and Ni et al. (2007) who found that supplementation daidzein as a phytoestrogen improving the laying performance during post peak laying of Shaoxing duck and in ISA layers where the amount of cracked eggs decreases while eggshell thickness and egg production increases.

The present findings illustrated that adding 3500 IU of vitamin D3 significantly improved the egg number but this improvement in egg mass was insignificant as compared to the basal diet. The results are agreement with those reported by Park et al. (2005) where in a 30-d experiment, diets containing 4,000, $8,000,12,000,16,000$, or 20,000 IU of Vitamin $\mathrm{D}_{3}$ showed no significant differences in feed intake and feed conversion ratio. Also, these results are in agreement with the findings of Atencio et al. (2006) who mentioned that the diets containing 2000 and $125 \mathrm{IU} / \mathrm{kg}$ hen's diet from 25 to 66 weeks resulted in the highest and the lowest percentages of hen 


\section{M.M. Beshara et al.}

day egg production respectively. Moreover, Nascimento et al. (2014) mentioned that cholecalciferol improved production performance and egg quality. On the other hand, Browning and Cowieson, (2015) found that a dietary level of cholecalciferol $(5000 \mathrm{IU} / \mathrm{Kg})$ increased egg weight without any other positive effects on laying performance, while Plaimast et al. (2015) observed improvement in egg shell quality in aged layers fed diets containing $6000 \mathrm{IU} / \mathrm{kg}$, however high vitamin D3 level did not improve the productive performance.

Reproductive performance:

The results in Table (5) showed that the diet supplemented with $4 \mathrm{~g}$ anise seeds powder resulted in a significant decrease in semen volume and semen concentration compared to the diet anethol source. But, no significant effect due to dietary anethol source on progressive motility of sperm. On the other hand, cocks fed diet supplemented with $180 \mathrm{mg}$ anise oil $/ \mathrm{kg}$ diet had higher mass motility than those fed the diet without anethol.

Moreover, no significant effect of dietary different levels of Vitamin $\mathrm{D}_{3}$ on all semen quality traits could be detected with exception the semen concentration where it was significantly improved by increase the level of vitamin $\mathrm{D}_{3}$ up to $3500 \mathrm{IU} / \mathrm{kg}$ diet compared to the diet contained $2000 \mathrm{IU}$ vitamin $\mathrm{D}_{3} / \mathrm{kg}$ diet.

Results showed that adding $4 \mathrm{~g}$ anise seed power $+3500 \mathrm{IU}$ vitamin $\mathrm{D}_{3} / \mathrm{kg}$ diet resulted in a significant increase in progressive motility compared to the basal diet while, the diet supplemented with $189 \mathrm{mg}$ anise oil + vitamin $\mathrm{D}_{3}(2750$ or $3500 \mathrm{IU} / \mathrm{kg}$ diet) significantly improved semen concentration as compared to the basal diet.
In respect of reproductive performance, no significant effect was observed on fertility $\%$ by feeding on diets supplemented with $4 \mathrm{~g}$ anise seed powder or 180 anise oil $/ \mathrm{kg}$ diets. On the other hand, the hatchability of total and fertile eggs $\%$ and chick weight at hatch significantly increased by addition $4 \mathrm{~g}$ anise seed powder/kg diet compared to the basal diet. Moreover, it is worth to mention that the diet supplemented with 2750 IU vitamin $\mathrm{D}_{3} / \mathrm{kg}$ diet had significantly the highest hatchability of fertile eggs and chick weight at hatch compared to the diet contained $2000 \mathrm{IU}$ vitamin $\mathrm{D}_{3} / \mathrm{kg}$ diet.

Results in Table (5) showed that there was a significant effect on all reproductive parameters due to combination between anethole source and vitamin $\mathrm{D}_{3}$ with exception the fertility $\%$. The results showed that the diet supplemented with $4 \mathrm{~g}$ anise seed powder $/ \mathrm{kg}$ diet $+2750 \mathrm{IU}$ vitamin $\mathrm{D}_{3}$ significantly ameliorated the hatchability of set eggs compared to the basal and other treatments with exception the eggs from hens fed diet with $4 \mathrm{~g}$ anise seed alone or with $3500 \mathrm{IU}$ vitamin $\mathrm{D}_{3} / \mathrm{kg}$ diet. Also, results of hatchability of fertile eggs come in accordance with those of commercial hatchability where the best value of hatchability of fertile eggs was in eggs from hens fed diet supplemented with $4 \mathrm{~g}$ anise seed +2750 vitamin $\mathrm{D}_{3} / \mathrm{kg}$ diet compared to the basal diet and other dietary treatments suggesting an synergistic effect between anise seed and vitamin $\mathrm{D}_{3}$. In addition all dietary treatments recorded higher values of chick weight at hatch than the diet with $2000 \mathrm{IU}$ vitamin $\mathrm{D}_{3}$ and free anethol.

The amelioration in reproductive performance is speculative, it may be attributed to the difference mechanism of 
Cholecalciferol - Anethole - Egg production - Fertility - Hatchability

anise seed and vitamin D3 on Sinai breeders and embryo where, it has already been reported that extract anise seed possessed antioxidant activity (Gulcin et al., 2003). Chick embryo may be subjected to stress where the development of embryo is associated with an accumulation of polyunsaturated fatty acids in tissue lipids (Speake et al., 1998) making them susceptible to lipid peroxidation (Surai, 1999a). Thus, adding anise seed to the breeder's diet may be decreasing the oxidation products transferred into the yolk (Botsoglou et al., 1997) and enhancement the antioxidant system of chick embryo. Bayram et al. (2007) reported that aniseed could be used in layer quail diets with an increased antioxidant activity and a decreased lipid peroxidation. In addition, this improvement can be explained by transanethole, which is the main component of the anise oil and it have a powerful phytoestrogen (Christaki et al., 2012).

The transfer of nutrients from the hen to the egg follows two pathways: via the ovary to the yolk or via the oviduct to the albumen, eggshell and membrane (Ding et al., 2011). Mattila et al. (1999) showed that vitamin D3 in the diet is transferred to the eggs; therefore, when more eggs are being produced, a higher output of $\mathrm{D}_{3}$ into the eggs is expected and, consequently, a higher $\mathrm{D}_{3}$ requirement. The study by Ameenuddin et al. (1986) showed that 40,000 IU of vitamin $\mathrm{D}_{3} / \mathrm{kg}$ of to be well tolerated by laying hens, but 200,000 IU of vitamin $D_{3} / \mathrm{kg}$ of diet decreased fertility\%.

Also, Edwards (1995) show that when the maternal diet contains only 500 IU of vitamin $\mathrm{D} 3 / \mathrm{kg}$, the chick cannot reach maximum growth while, when the maternal diet contains 2,000 IU/kg, high levels of chicks growth is achieved. According to Atencio et al. (2006) five levels of vitamin $\mathrm{D}_{3}(125,250,500$, 1,000 , and $2,000 \mathrm{IU} / \mathrm{kg}$ of diet) were fed to hens from 25 to 66 weeks of age, who found that the highest and the lowest percentages of hatchability were observed in the hens that received the highest and the lowest vitamin $\mathrm{D}_{3}$ but, no vitamin $\mathrm{D}_{3}$ effects were observed on fertility or body weight of the progeny at $1 \mathrm{~d}$ of age. Generally, the results obtained in this experiment which showed the important role of vitamin $\mathrm{D}_{3}$ in improving breeder hen's performance.

Blood serum traits:

No significant alternations were detected in total protein, albumin, globulin and phosphorus in blood serum due to dietary anise seed powder or anise oil supplementation as shown in Table 6 . However, it is evident that calcium content in serum significantly decreased for hens fed diet supplemented with 180 $\mathrm{mg}$ anise oil/ $\mathrm{kg}$ diet compared to the basal diet.

In addition, different levels of vitamin $\mathrm{D}_{3}$ did not appear to influence on all blood serum estimates except for the calcium and phosphorus levels where hens fed 3500 IU vitamin $\mathrm{D}_{3} / \mathrm{kg}$ diet had lower calcium level in blood serum than those fed control and $2750 \mathrm{IU}$ vitamin $\mathrm{D}_{3} / \mathrm{kg}$ diet, while hens fed diet with 2750 IU vitamin $\mathrm{D}_{3} / \mathrm{kg}$ diet had significantly the highest phosphors in blood serum compared to the diet contained $2000 \mathrm{IU} /$ $\mathrm{kg}$ diet.

It is clearly observed that the combination between $180 \mathrm{mg}$ anise oil and $3500 \mathrm{IU}$ vitamin $\mathrm{D}_{3} / \mathrm{kg}$ diet and $4 \mathrm{~g}$ anise seed + basal diet resulted in a significant 


\section{M.M. Beshara et al.}

increase total protein in serum compared to the basal diet. On the other hand, no significant effect due to interaction between dietary treatments on blood serum albumin, but serum globulin level significantly increased as a result of interaction between $4 \mathrm{~g}$ anise seed power + basal diet or with 3500IU vitamin $\mathrm{D}_{3} / \mathrm{kg}$ diet and $180 \mathrm{mg}$ anise oil/ $\mathrm{kg}$ diet + 2750 or $3500 \mathrm{IU}$ vitamin $\mathrm{D}_{3} / \mathrm{kg}$ diet compared to the basal diet.

The calcium level in blood serum was decreased by all dietary combination treatments especially the combination between $180 \mathrm{mg}$ anise oil and $3500 \mathrm{IU}$ vitamin $\mathrm{D}_{3} \quad / \mathrm{kg}$ diet where it was significantly decrease by about $33.12 \%$ as compared to basal diet. This effect is to be expected, as the improvement in egg production due to adding $180 \mathrm{mg}$ anise oil, the high level of vitamin $\mathrm{D}_{3} / \mathrm{kg}$ diet and interaction between the same treatments may be does not allow enough time for increase the calcium level in blood, where, calcium and phosphate serum levels thus depend on egg formation and are not constant throughout the day (Choi et al., 1979). The beneficial properties of anise such as antioxidant activity (Gulcin et al., 2003) were reflected in the cellular and biochemical traits of blood serum as a result from the improvement of biological, metabolic parameters and optimized utilization of nutrients in the digestive system thus anise oil enhance blood levels of total protein and globulin.

Interaction between basal diet, $4 \mathrm{~g}$ anise seed and $180 \mathrm{mg}$ anise oil +2750 vitamin $\mathrm{D}_{3} / \mathrm{kg}$ diet significantly increased the level of $\mathrm{P}$ in serum compared to the basal diet. These results have some support from a study by Ali et al. (2007) who clarified that addition thyme numerically increased plasma phosphorus and calcium.

The estrogen activity due to adding anise seed may be explained these results related to calcium level in serum, egg shell and tibia where estrogen is hypothesized to affect $\mathrm{Ca} 2+$ transport in the duodenum by up-regulation of calcium channels (Van Cromphaut et al., 2003), but also by stimulating the conversion of vitamin $\mathrm{D}_{3}$ to its biologically active form calcitriol (Castillo et al., 1977).

The results in the current study demonstrate that the medium level (2750 IU vitamin $\mathrm{D} 3 / \mathrm{kg}$ ) of vitamin $\mathrm{D}_{3}$ resulted in a slight increase in blood serum calcium while the hens fed diet contained 2750 IU vitamin D3 / $/ \mathrm{kg}$ diet had significantly the highest value of serum $\mathrm{P}$ than control diet. In fact, vitamin $\mathrm{D}_{3}$ hormone functions to increase serum calcium concentrations through some separate activities. First, it is the only hormone known to induce the proteins involved in active intestinal calcium absorption. Furthermore, it stimulates active intestinal absorption of phosphate. Second, blood calcium concentrations remain in the normal range even when an animal is placed on a no-calcium diet. Therefore, an animal must possess the ability to mobilize calcium in the absence of calcium coming from the environment, ie, through enterocytes (Suda et al., 2002). However, the decrease level of serum calcium due to high level of vitamin $\mathrm{D}_{3}$ in the diet may be attributed to the effect of including this level of vitamin $\mathrm{D}_{3}$ in the diet on egg production as shown in Table 3.

Egg shell and bone chemical composition:

Results in Table (7) showed that a significant decreased in egg shell calcium 
Cholecalciferol - Anethole - Egg production - Fertility - Hatchability

level $(\mathrm{mg} / \mathrm{g})$ due to adding $4 \mathrm{~g}$ anise seed powder and 180 anise oil/ $\mathrm{kg}$ diet compared to the diet free anethol, but no significant effect on phosphorus level in egg shell and calcium in tibia. On the other hand, tibia phosphorus significantly increased by the diet supplemented with $4 \mathrm{~g}$ anise seed $/ \mathrm{kg}$ diet compared to the diet free anethol. Moreover, the diet supplemented with 2750 and 3500 IU vitamin $\mathrm{D}_{3} / \mathrm{kg}$ diet tend to decrease egg shell calcium but, the high level of vitamin $\mathrm{D}_{3}$ resulted in a significant increase in tibia phosphorus compared to the diet contained $2000 \mathrm{IU}$ vitamin $\mathrm{D}_{3} / \mathrm{kg}$ diet. No significant differences on egg shell phosphorus and tibia calcium due to the different levels of vitamin $\mathrm{D}_{3}$.

In this respect, results revealed that the calcium level in egg shell was significantly decreased due to most the combination dietary treatments as compared to the basal. Also, the phosphorus level in egg shell significantly decreased due to the interaction between $180 \mathrm{mg}$ anise oil $\mathrm{x}$ $3500 \mathrm{IU}$ vitamin $\mathrm{D}_{3} / \mathrm{kg}$ diet compared to basal diet. On the other hand, calcium level in tibia was significantly higher by adding $2750 \mathrm{IU}$ vitamin $\mathrm{D}_{3} / \mathrm{kg}$ diet than basal group. Also, both $180 \mathrm{mg}$ anise oil + basal or with 2750 IU vitamin $\mathrm{D}_{3}$ resulted in a significant decrease in phosphorus level in tibia compared to the basal diet. In fact, the availability of calcium depends on intestinal absorption from feed, but the skeleton also acts as a source of calcium during the dark hours of the day, when intestinal absorption has decreased.
No significant effects due to adding 6,000 and 15,000 IU vitamin D3/kg layer's diet on egg quality in a 48-wk feeding experiment (Mattila et al., 2004). Also, in a 30-d experiment, diets containing 4,000, $8,000,12,000,16,000$, or 20,000 IU of D3 showed no significant differences in eggshell strength, Haugh unit, or egg yolk color (Park et al., 2005).

Browning and Cowieson (2015) found that $5000 \mathrm{IU} / \mathrm{Kg}$ cholecalciferol $/ \mathrm{kg}$ diet did not effect on egg shell quality and tibia mineralization, while Plaimast et al. (2015) observed improved egg shell quality in aged layers fed diet containing $6000 \mathrm{IU} / \mathrm{kg}$ diet.

Economic efficiency (EEF):

As shown in Table (8), hens fed diet supplemented with $3500 \mathrm{IU}$ vitamin $\mathrm{D}_{3} /$ $\mathrm{kg}$ diet and those fed diet contained 180 $\mathrm{mg}$ anise oil $+3500 \mathrm{IU}$ vitamin $\mathrm{D}_{3} / \mathrm{kg}$ diet produced higher EEF than basal diet.

\section{CONCLUSION}

It could be concluded that the addition $180 \mathrm{mg}$ anise oil + 3500 IU vitamin $\mathrm{D}_{3} / \mathrm{kg}$ diet in Sinai laying hens diets can be used to maximize the productive performance and economic efficiency. In addition, the diet supplemented with $4 \mathrm{~g}$ anise seed powder +2750 or 3500 IU vitamin $\mathrm{D}_{3}$ can be used to improvement the hatchability of set and fertile eggs. 
M.M. Beshara et al.

Table (1): Ingredients and calculated analysis of the layer diet

\begin{tabular}{|c|c|}
\hline Ingredients & $\%$ \\
\hline Yellow corn & 64.00 \\
\hline Soy bean meal (44\%) & 22.50 \\
\hline Corn gluten $(60 \%)$ & 1.58 \\
\hline Wheat bran & 1.68 \\
\hline Di-calcium phosphate & 1.40 \\
\hline Limestone & 8.14 \\
\hline premix ${ }^{1}$ & 0.30 \\
\hline Sodium chloride & 0.30 \\
\hline DL- Methionine (99\%) & 0.10 \\
\hline Total & 100 \\
\hline \multicolumn{2}{|l|}{ Calculated Analysis ${ }^{2}$} \\
\hline Crude protein $\%$ & 16.10 \\
\hline ME ( Kcal / kg ) & 2730 \\
\hline Crude fiber $\%$ & 3.30 \\
\hline Ether extract $\%$ & 2.87 \\
\hline Calcium (\%) & 3.43 \\
\hline Av. Phosphorus (\%) & 0.39 \\
\hline Methionine \% & 0.40 \\
\hline Lysine & 0.84 \\
\hline Methionine + Cystin \% & 0.68 \\
\hline Price $(\mathrm{LE} / \mathrm{kg} \text { diet })^{3}$ & 5.02 \\
\hline
\end{tabular}

1-Each $3 \mathrm{~kg}$ of vitamins and Minerals premix contains 100 million IU vitamin A; 2 million IU Vit.D3;10 g vitamin $\mathrm{E} ; 1 \mathrm{~g}$ Vit. $\mathrm{K}_{3} ; 1 \mathrm{~g}$ vitaminB $1 ; 5 \mathrm{~g}$ vitamin $\mathrm{B} 2 ; 10 \mathrm{mg}$ vitamin $\mathrm{B} 12 ; 1.5 \mathrm{~g}$ vitamin B6; $30 \mathrm{~g}$ Niacin ; $10 \mathrm{~g}$ Pantothenic acid ;1g Folic acid; $50 \mathrm{mg}$ Biotin ; $300 \mathrm{~g}$ Choline chloride; $50 \mathrm{~g}$ Zinc; $4 \mathrm{~g}$ Copper; $0.3 \mathrm{~g}$ Iodine ; $30 \mathrm{~g}$ Iron; $0.1 \mathrm{~g}$ Selenium; 60g Manganese ; $0.1 \mathrm{~g}$ Cobalt; and carrier $\mathrm{CaCO}_{3}$ to $3000 \mathrm{~g}$. 2- According to Feed Composition Tables for animal and poultry feedstuffs used in Egypt (2001). 3- Price of one kg (Egyptian pound / $\mathrm{kg}$ diet) for different ingredients: Yellow corn, 3.95 ; Soybean meal 8.0 ; Wheat bran, 2.42 ; Corn gluten, 13.8 ; Di-calcium phosphate, 10.8 ; Limestone, 0.2; Premix, 60.0; Salt, 0.50; Dl - methionine, 70.0; anise seeds, 40; $100 \mathrm{ml}$ anise oil, 350 . 
Table (2): Egg performance of local Sinai hens as an effect to fed diets contained different levels of anethol and vitamin $\mathrm{D}_{3}$

\begin{tabular}{|c|c|c|c|c|c|c|c|c|c|c|c|}
\hline \multirow{2}{*}{\multicolumn{2}{|c|}{$\begin{array}{r}\text { Traits } \\
\text { Treatments }\end{array}$}} & \multicolumn{5}{|c|}{ Egg number } & \multicolumn{5}{|c|}{ Egg weight/g } \\
\hline & & $25-28$ & 29-32 & 33-36 & $37-40$ & $25-40$ & $25-28$ & 29-32 & 33-36 & $37-40$ & $25-40$ \\
\hline \multicolumn{12}{|c|}{ Source of trans-anethole } \\
\hline 0 & & $11.26^{\mathrm{b}}$ & $16.06^{\mathrm{a}}$ & $14.39^{\mathrm{b}}$ & $16.19^{\mathrm{ab}}$ & $57.89^{\mathrm{b}}$ & 40.0 & 43.7 & $50.71^{\mathrm{b}}$ & $51.25^{\mathrm{b}}$ & 46.4 \\
\hline $4 \mathrm{~g}$ an & & $10.33^{\mathrm{b}}$ & $14.03^{\mathrm{c}}$ & $16.2^{\mathrm{a}}$ & $15.93^{\mathrm{b}}$ & $56.51^{\mathrm{b}}$ & 38.3 & 43.7 & $51.71^{\mathrm{a}}$ & $53.20^{\mathrm{a}}$ & 46.7 \\
\hline $180 \mathrm{mg}$ & & $12.33^{\mathrm{a}}$ & $14.94^{\mathrm{b}}$ & $16.22^{\mathrm{a}}$ & $17.41^{\mathrm{a}}$ & $60.91^{\mathrm{a}}$ & 40.9 & 43.4 & $51.55^{\mathrm{ab}}$ & $51.94^{\mathrm{ab}}$ & 47.0 \\
\hline$\pm \mathrm{SE}$ & & 0.32 & 0.21 & 0.54 & 0.44 & 1.07 & 1.85 & 0.43 & 0.29 & 0.50 & 0.49 \\
\hline Sig & & 0.05 & 0.05 & 0.05 & 0.05 & 0.05 & NS & NS & 0.05 & 0.05 & NS \\
\hline \multicolumn{12}{|c|}{ Vitamin $\mathrm{D}_{\mathbf{3}}$} \\
\hline 2000 & & $10.96^{\mathrm{b}}$ & $13.28^{\mathrm{b}}$ & 16.00 & 16.72 & $56.96^{\mathrm{b}}$ & 40.9 & 43.97 & 51.36 & 52.29 & 47.1 \\
\hline 2750 & & $10.85^{\mathrm{b}}$ & $15.15^{\mathrm{b}}$ & 14.89 & 16.30 & $57.23^{\mathrm{b}}$ & 39.7 & 43.26 & 51.58 & 52.38 & 46.7 \\
\hline 3500 & & $12.11^{\mathrm{a}}$ & $16.56^{\mathrm{a}}$ & 15.94 & 16.50 & $61.11^{\mathrm{a}}$ & 38.6 & 43.52 & 51.02 & 51.72 & 46.2 \\
\hline$\pm \mathrm{SE}$ & & 0.32 & 0.21 & 0.54 & 0.44 & 1.07 & 1.85 & 0.43 & 0.29 & 0.50 & 0.49 \\
\hline \multicolumn{12}{|c|}{ Anethol and vitamin D3 } \\
\hline \multirow{3}{*}{0} & 2000 & $12.22^{\mathrm{bc}}$ & $14.08^{\text {cd }}$ & $14.67^{\mathrm{ab}}$ & 15.83 & $56.81^{\mathrm{b}}$ & 42.8 & $43.43^{\mathrm{ab}}$ & $50.69^{\mathrm{bcd}}$ & $50.75^{\mathrm{b}}$ & 46.9 \\
\hline & 2750 & $10.67^{\text {cde }}$ & $17.17^{b}$ & $13.44^{\mathrm{b}}$ & 16.28 & $57.56^{\mathrm{b}}$ & 39.2 & $42.87^{\mathrm{ab}}$ & $49.15^{\mathrm{d}}$ & $50.69^{\mathrm{b}}$ & 45.5 \\
\hline & 3500 & $10.89^{\text {bcde }}$ & $16.92^{\mathrm{b}}$ & $15.06^{\mathrm{ab}}$ & 16.44 & $59.31^{\mathrm{b}}$ & 38.0 & $44.73^{\mathrm{a}}$ & $52.28^{\mathrm{ab}}$ & $52.31^{\mathrm{ab}}$ & 46.8 \\
\hline & 2000 & $10.39^{\mathrm{de}}$ & $13.50^{\mathrm{d}}$ & $16.89^{\mathrm{a}}$ & 16.39 & $57.17^{\mathrm{b}}$ & 37.7 & $43.75^{\mathrm{ab}}$ & $51.39^{\mathrm{abc}}$ & $53.41^{\mathrm{ab}}$ & 46.6 \\
\hline \multirow{2}{*}{$\begin{array}{l}4 \mathrm{~g} \\
\text { anise }\end{array}$} & 2750 & $9.39^{\mathrm{e}}$ & $15.08^{c}$ & $15.00^{\mathrm{ab}}$ & 16.00 & $55.43^{\mathrm{b}}$ & 38.7 & $45.02^{\mathrm{a}}$ & $52.96^{\mathrm{a}}$ & $54.20^{\mathrm{a}}$ & 47.7 \\
\hline & 3500 & $11.22^{\text {bcde }}$ & $13.50^{\mathrm{d}}$ & $16.78^{\mathrm{a}}$ & 15.39 & $56.89^{\mathrm{b}}$ & 38.5 & $42.22^{\mathrm{b}}$ & $50.78^{\mathrm{bc}}$ & $51.98^{\mathrm{ab}}$ & 45.9 \\
\hline 180 & 2000 & $10.28^{\mathrm{de}}$ & $12.25^{\mathrm{e}}$ & $16.44^{\mathrm{ab}}$ & 17.94 & $56.92^{\mathrm{b}}$ & 42.2 & $44.71^{\mathrm{a}}$ & $52.02^{\mathrm{ab}}$ & $52.70^{\mathrm{ab}}$ & 47.9 \\
\hline $\mathrm{mg}$ & 2750 & $12.50^{\mathrm{bc}}$ & $13.33^{\mathrm{d}}$ & $16.22^{\mathrm{ab}}$ & 16.61 & $58.67^{\mathrm{b}}$ & 41.1 & $41.88^{\mathrm{b}}$ & $52.62^{\mathrm{a}}$ & $52.26^{\mathrm{ab}}$ & 47.0 \\
\hline oil & 3500 & $14.22^{\mathrm{a}}$ & $19.25^{\mathrm{a}}$ & $16.00^{\mathrm{ab}}$ & 17.67 & $67.14 \mathrm{a}$ & 39.4 & $43.62^{\mathrm{ab}}$ & $50.02^{\text {cd }}$ & $50.87^{\mathrm{b}}$ & 46.0 \\
\hline \multicolumn{2}{|c|}{$\pm \mathrm{SE}$} & 0.55 & 0.36 & 0.93 & 0.76 & 1.86 & 3.20 & 0.74 & 0.49 & 0.87 & 0.86 \\
\hline
\end{tabular}

a,b,c,d,e: means in the same column bearing different superscripts are significantly different ( $\leq \leq 0.05)$; NS= Non significant 
M.M. Beshara et al.

Table (3): Egg mass of local Sinai hens as an effect to fed diets contained different levels of anethol and vitamin $\mathrm{D}_{3}$

\begin{tabular}{|c|c|c|c|c|c|c|}
\hline \multirow{2}{*}{\multicolumn{2}{|c|}{$\begin{array}{c}\text { Traits } \\
\text { Treatments }\end{array}$}} & \multicolumn{5}{|c|}{ Egg mass } \\
\hline & & $25-28$ & 29-32 & 33-36 & $37-40$ & $25-40$ \\
\hline \multicolumn{7}{|c|}{ Source of trans-anethole } \\
\hline \multirow{5}{*}{\multicolumn{2}{|c|}{$\begin{array}{l}0 \\
4 \mathrm{~g} \text { anise } \\
180 \mathrm{mg} \text { oil } \\
\pm \mathrm{SE} \\
\mathrm{Sig}\end{array}$}} & $454.2^{\mathrm{ab}}$ & $701.5 \mathrm{a}$ & $729.5^{b}$ & $829.5 b$ & $2687^{\mathrm{ab}}$ \\
\hline & & $397.9^{b}$ & $613.3 c$ & $837.5 \mathrm{a}$ & $846.4^{\mathrm{ab}}$ & $2638.4^{\mathrm{b}}$ \\
\hline & & $503.7^{\mathrm{a}}$ & $648.5^{b}$ & $836.2 \mathrm{a}$ & $904.7^{\mathrm{c}}$ & $2856.6^{\mathrm{a}}$ \\
\hline & & 30.02 & 10.76 & 25.04 & 23.27 & 58.81 \\
\hline & & 0.05 & 0.05 & 0.05 & 0.05 & 0.05 \\
\hline \multicolumn{7}{|c|}{ Vitamin $\mathbf{D}_{3}$} \\
\hline \multirow{5}{*}{\multicolumn{2}{|c|}{$\begin{array}{l}2000 \\
2750 \\
3500 \\
\pm \mathrm{SE} \\
\mathrm{Sig}\end{array}$}} & 450.34 & $583.3 \mathrm{c}$ & 821.7 & 874.4 & 2685.1 \\
\hline & & 433.30 & $657.8 b$ & 769.1 & 853.1 & 2673.7 \\
\hline & & 472.25 & $722.1 \mathrm{a}$ & 812.5 & 853.1 & 2823.5 \\
\hline & & 30.02 & 10.76 & 25.04 & 23.37 & 58.81 \\
\hline & & NS & 0.05 & NS & NS & NS \\
\hline \multicolumn{7}{|c|}{ Anethol and vitamin D3 } \\
\hline \multirow{3}{*}{0} & 2000 & $524.78^{\mathrm{ab}}$ & $612.0^{\mathrm{d}}$ & $742.0^{\mathrm{ab}}$ & $804.1^{\mathrm{b}}$ & $2667.1^{\mathrm{b}}$ \\
\hline & 2750 & $419.06^{\mathrm{ab}}$ & $735.9^{b}$ & $660.7^{b}$ & $824.7^{\mathrm{ab}}$ & $2618.3^{b}$ \\
\hline & 3500 & $418.93^{\mathrm{ab}}$ & $756.6^{\mathrm{b}}$ & $785.9^{\mathrm{ab}}$ & $859.9^{\mathrm{ab}}$ & $2776.9^{\mathrm{ab}}$ \\
\hline $4 \mathrm{~g}$ & 2000 & $392.31^{\mathrm{ab}}$ & $590.6^{\mathrm{de}}$ & $867.5^{\mathrm{a}}$ & $873.8^{\mathrm{ab}}$ & $2660.4^{b}$ \\
\hline \multirow[t]{2}{*}{ anise } & 2750 & $366.46^{\mathrm{b}}$ & $679.2^{\mathrm{c}}$ & $793.4^{\mathrm{ab}}$ & $866.3^{\mathrm{ab}}$ & $2647.7^{\mathrm{b}}$ \\
\hline & 3500 & $435.07^{\mathrm{ab}}$ & $570.0^{\mathrm{de}}$ & $851.6^{\mathrm{a}}$ & $799.0^{\mathrm{b}}$ & $2607.1^{b}$ \\
\hline 180 & 2000 & $433.95^{\mathrm{ab}}$ & $547.3^{\mathrm{e}}$ & $855.5^{\mathrm{a}}$ & $945.3^{\mathrm{a}}$ & $2727.9^{b}$ \\
\hline $\mathrm{mg}$ & 2750 & $514.38^{\mathrm{ab}}$ & $558.4^{\mathrm{de}}$ & $852.9^{\mathrm{a}}$ & $868.4^{\mathrm{ab}}$ & $2755.2^{\mathrm{ab}}$ \\
\hline oil & 3500 & $562.75^{a}$ & $839.7^{a}$ & $800.2^{\mathrm{ab}}$ & $900.5^{\mathrm{ab}}$ & $3086.6^{\mathrm{a}}$ \\
\hline \multicolumn{2}{|c|}{$\pm \mathrm{SE}$} & 52.00 & 18.63 & 43.36 & 40.47 & 101.87 \\
\hline
\end{tabular}

a,b,c,d,e: means in the same column bearing different superscripts are significantly different $(\mathrm{p} \leq 0.05) ; \mathrm{NS}=$ Non significant 
Table (4): Feed intake and feed conversion of local Sinai hens as an effect to fed diets contained different levels of anethol and vitamin $\mathrm{D}_{3}$

\begin{tabular}{|c|c|c|c|c|c|c|c|c|c|c|c|}
\hline \multirow{2}{*}{\multicolumn{2}{|c|}{$\begin{array}{r}\text { Traits } \\
\text { Treatments } \\
\end{array}$}} & \multicolumn{5}{|c|}{ Feed intake (g/hen/day) } & \multicolumn{5}{|c|}{ Feed conversion ratio } \\
\hline & & $25-28$ & 29-32 & $33-36$ & $37-40$ & $25-40$ & $25-28$ & $29-32$ & 33-36 & $37-40$ & $25-40$ \\
\hline \multicolumn{12}{|c|}{ Source of trans-anethole } \\
\hline \multicolumn{2}{|l|}{0} & 86.95 & 106.29 & 112.20 & 124.67 & 107.53 & $5.56^{\mathrm{ab}}$ & $4.29^{\mathrm{b}}$ & $4.36^{\mathrm{a}}$ & 4.22 & 4.49 \\
\hline \multicolumn{2}{|c|}{$4 \mathrm{~g}$ anise } & 86.09 & 103.45 & 111.42 & 123.80 & 106.19 & $6.34^{\mathrm{a}}$ & $4.77^{\mathrm{a}}$ & $3.76^{\mathrm{b}}$ & 4.12 & 4.53 \\
\hline \multicolumn{2}{|c|}{$180 \mathrm{mg}$ oil } & 87.35 & 103.67 & 112.66 & 125.18 & 107.22 & $4.97^{\mathrm{b}}$ & $4.65^{\mathrm{ab}}$ & $3.80^{\mathrm{b}}$ & 3.91 & 4.22 \\
\hline \multicolumn{2}{|c|}{$\pm \mathrm{SE}$} & 20.02 & 2.29 & 0.74 & 0.83 & 0.90 & 0.40 & 0.14 & 0.14 & 0.12 & 0.11 \\
\hline \multicolumn{2}{|l|}{ Sig } & NS & NS & $\mathrm{NS}$ & NS & NS & 0.05 & 0.05 & 0.05 & NS & NS \\
\hline \multicolumn{12}{|c|}{ Vitamin $D_{3}$} \\
\hline \multicolumn{2}{|c|}{2000} & 88.34 & 104.63 & 112.37 & 124.85 & 107.55 & 5.62 & $5.05 \mathrm{a}$ & 3.87 & 4.03 & 4.51 \\
\hline \multicolumn{2}{|l|}{2750} & 87.40 & 104.43 & 111.98 & 124.42 & 107.06 & 5.95 & $4.50 \mathrm{~b}$ & 4.16 & 4.10 & 4.51 \\
\hline \multicolumn{2}{|l|}{3500} & 84.65 & 104.35 & 111.93 & 124.37 & 106.33 & 5.29 & $4.15 b$ & 3.88 & 4.12 & 4.23 \\
\hline \multicolumn{2}{|l|}{$\pm \mathrm{SE}$} & 20.2 & 2.29 & 0.74 & 0.83 & 0.90 & 0.40 & 0.14 & 0.14 & 0.12 & 0.11 \\
\hline \multicolumn{12}{|c|}{ Source of Trans-anethol and vitamin D3 } \\
\hline \multirow{3}{*}{0} & 2000 & $90.1^{\mathrm{ab}}$ & 106.01 & 111.60 & 124.00 & 107.93 & $4.90^{\mathrm{ab}}$ & $4.86^{\mathrm{ab}}$ & $4.24^{\mathrm{ab}}$ & 4.34 & $4.56^{\mathrm{ab}}$ \\
\hline & 2750 & $87.2^{\mathrm{ab}}$ & 110.54 & 112.90 & 125.44 & 109.02 & $5.91^{\mathrm{ab}}$ & $4.21^{\mathrm{bc}}$ & $4.84^{\mathrm{a}}$ & 4.26 & $4.67^{\mathrm{a}}$ \\
\hline & 3500 & $83.6^{\mathrm{ab}}$ & 102.32 & 112.10 & 124.56 & 105.63 & $5.86^{\mathrm{ab}}$ & $3.79^{c}$ & $4.02^{\mathrm{b}}$ & 4.07 & $4.24^{\mathrm{ab}}$ \\
\hline \multirow{3}{*}{$\begin{array}{l}4 \mathrm{~g} \\
\text { anise }\end{array}$} & 2000 & $90.4^{\mathrm{ab}}$ & 105.41 & 112.90 & 125.44 & 108.54 & $6.48^{\mathrm{ab}}$ & $5.01^{\mathrm{a}}$ & $3.67^{\mathrm{b}}$ & 4.03 & $4.60^{\mathrm{a}}$ \\
\hline & 2750 & $88.8^{\mathrm{ab}}$ & 101.79 & 110.05 & 122.28 & 105.74 & $7.19^{\mathrm{a}}$ & $4.22^{\mathrm{bc}}$ & $3.92^{\mathrm{b}}$ & 3.97 & $4.51^{\mathrm{ab}}$ \\
\hline & 3500 & $79.0^{\mathrm{b}}$ & 103.14 & 111.30 & 123.67 & 104.28 & $5.34^{\mathrm{ab}}$ & $5.06^{\mathrm{a}}$ & $3.68^{\mathrm{b}}$ & 4.36 & $4.49^{\mathrm{ab}}$ \\
\hline \multirow{4}{*}{$\begin{array}{l}180 \\
\text { mg } \\
\text { oil }\end{array}$} & 2000 & $84.5^{\mathrm{ab}}$ & 102.47 & 112.60 & 125.11 & 106.18 & $5.49^{\mathrm{ab}}$ & $5.26^{\mathrm{a}}$ & $3.70^{\mathrm{b}}$ & 3.73 & $4.38^{\mathrm{ab}}$ \\
\hline & 2750 & $86.2^{\mathrm{ab}}$ & 100.96 & 112.98 & 125.53 & 106.41 & $4.75^{\mathrm{b}}$ & $5.06^{\mathrm{a}}$ & $3.72^{\mathrm{b}}$ & 4.07 & $4.34^{\mathrm{ab}}$ \\
\hline & 3500 & $91.4^{\mathrm{a}}$ & 107.60 & 112.40 & 124.89 & 109.06 & $4.68^{\mathrm{b}}$ & $3.60^{c}$ & $3.96^{\mathrm{b}}$ & 3.92 & $3.95^{\mathrm{b}}$ \\
\hline & $\pm \mathrm{SE}$ & 3.5 & 3.96 & 1.29 & 1.43 & 0.28 & 0.24 & 0.25 & 0.20 & 0.19 & 0.28 \\
\hline
\end{tabular}

a,b,c,: means in the same column bearing different superscripts are significantly different $(\mathrm{p} \leq 0.05) ; \mathrm{NS}=$ Non significant 
Table (5): Reproductive performance of local Sinai hens fed diets containing different levels of anethol and vitamin D3

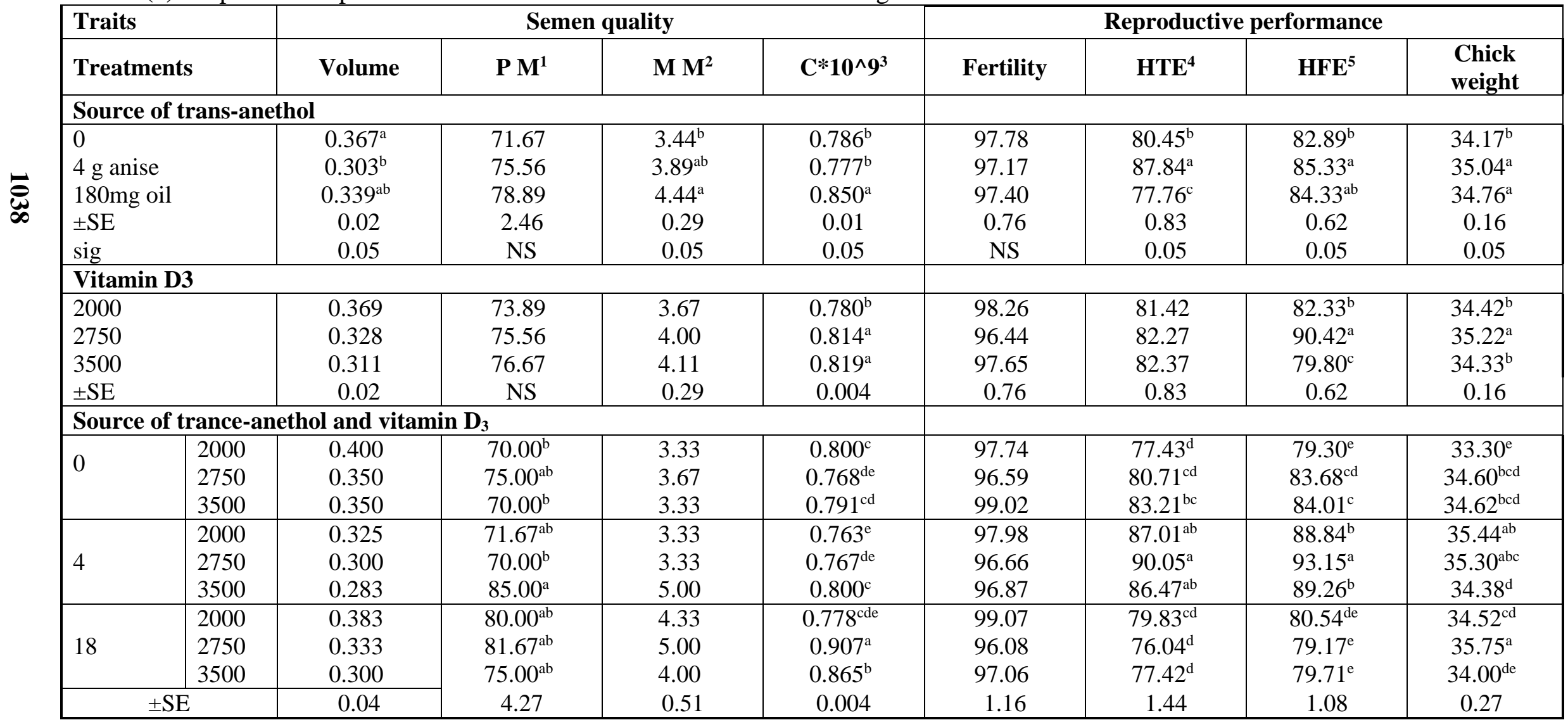

a,b,c,d,e: means in the same column bearing different superscripts are significantly different ( $\leq 0.05)$; NS $=$ Non significant; ${ }^{1} \mathrm{PM}=$ progressive motility; ${ }^{2} \mathrm{MM}=$ mass motility; ${ }^{3} \mathrm{C}^{*} 10^{\wedge} 9^{3}=$ Semen concentration; ${ }^{4} \mathrm{THE}=$ hatchability of total eggs; ${ }^{5} \mathrm{HFE}=$ hatchability of fertile eggs. 
Table (6): Blood serum traits of Sinai hens fed diets containing different levels of anethol and vitamin D3

\begin{tabular}{|c|c|c|c|c|c|c|}
\hline \multirow{2}{*}{\multicolumn{2}{|c|}{$\begin{array}{l}\text { Traits } \\
\text { Treatments }\end{array}$}} & \multicolumn{5}{|c|}{ Blood traits } \\
\hline & & $\begin{array}{c}\text { T. protein } \\
\text { (g/dl) }\end{array}$ & $\begin{array}{l}\text { Albumin } \\
\text { (g/dl) }\end{array}$ & $\begin{array}{l}\text { Globulin } \\
\text { (g/dl) }\end{array}$ & $\begin{array}{c}\text { Calcium } \\
\text { (mg/dl) }\end{array}$ & $\begin{array}{c}\text { Phosphorus } \\
\text { (mg/dl) }\end{array}$ \\
\hline \multicolumn{7}{|c|}{ Source of trans-anethol } \\
\hline \multirow{5}{*}{\multicolumn{2}{|c|}{$\begin{array}{l}0 \\
4 \mathrm{~g} \text { anise seed } \\
180 \mathrm{mg} \text { oil } \\
\pm \mathrm{SE} \\
\mathrm{Sig}\end{array}$}} & 5.02 & 2.70 & 2.32 & $24.81^{\mathrm{a}}$ & 6.24 \\
\hline & & 5.44 & 2.68 & 2.76 & $23.4^{\mathrm{ab}}$ & 6.41 \\
\hline & & 5.43 & 2.78 & 2.65 & $22.71^{b}$ & 6.36 \\
\hline & & 0.15 & 0.17 & 0.18 & 0.18 & 0.25 \\
\hline & & NS & NS & NS & 0.05 & NS \\
\hline \multicolumn{7}{|c|}{ Vitamin $\mathrm{D}_{3}$} \\
\hline \multicolumn{2}{|c|}{2000} & 5.23 & 2.52 & 2.71 & $24.27^{\mathrm{a}}$ & $6.00^{\mathrm{b}}$ \\
\hline \multicolumn{2}{|c|}{2750} & 5.15 & 2.68 & 2.48 & $24.51^{\mathrm{a}}$ & $7.25^{\mathrm{a}}$ \\
\hline \multicolumn{2}{|c|}{3500} & 5.50 & 2.96 & 2.54 & $22.17^{\mathrm{b}}$ & $5.76^{b}$ \\
\hline \multicolumn{2}{|c|}{$\pm \mathrm{SE}$} & 0.15 & 0.17 & 0.15 & 0.18 & 0.25 \\
\hline \multicolumn{2}{|l|}{ Sig } & NS & NS & NS & 0.05 & 0.05 \\
\hline \multicolumn{7}{|c|}{ Source of trance-anethol and vitamin D3 } \\
\hline \multirow{3}{*}{0} & 2000 & $4.72^{b}$ & 2.63 & $2.09^{c}$ & $27.54^{\mathrm{a}}$ & $5.28^{\mathrm{d}}$ \\
\hline & 2750 & $5.02^{\mathrm{ab}}$ & 2.98 & $2.04^{\mathrm{c}}$ & $24.51^{\mathrm{bc}}$ & $7.49^{\mathrm{a}}$ \\
\hline & 3500 & $5.32^{\mathrm{ab}}$ & 2.50 & $2.82^{\mathrm{abc}}$ & $22.41^{\mathrm{c}}$ & $5.97^{\mathrm{cd}}$ \\
\hline \multirow{3}{*}{4} & 2000 & $5.78^{\mathrm{a}}$ & 2.43 & $3.35^{\mathrm{a}}$ & $19.80^{\mathrm{de}}$ & $6.33^{\mathrm{abcd}}$ \\
\hline & 2750 & $4.97^{\mathrm{ab}}$ & 2.62 & $2.35^{\mathrm{bc}}$ & $24.72^{\mathrm{abc}}$ & $6.86^{\mathrm{abc}}$ \\
\hline & 3500 & $5.57^{\mathrm{ab}}$ & 2.90 & $2.58^{\mathrm{abc}}$ & $25.65^{\mathrm{ab}}$ & $6.03^{\mathrm{bcd}}$ \\
\hline \multirow{3}{*}{180} & 2000 & $5.18^{\mathrm{ab}}$ & 2.51 & $2.68^{\mathrm{abc}}$ & $25.44^{\mathrm{ab}}$ & $6.40^{\text {abcd }}$ \\
\hline & 2750 & $5.47^{\mathrm{ab}}$ & 2.43 & $3.05^{\mathrm{ab}}$ & $24.27^{b c}$ & $7.42^{\mathrm{ab}}$ \\
\hline & 3500 & $5.62^{\mathrm{a}}$ & 3.40 & $2.22^{\mathrm{abc}}$ & $18.42^{\mathrm{e}}$ & $5.28^{\mathrm{d}}$ \\
\hline \multicolumn{2}{|c|}{$\pm \mathrm{SE}$} & 0.26 & 0.30 & 0.31 & 0.31 & 0.44 \\
\hline \multicolumn{2}{|l|}{ Sig } & 0.05 & NS & 0.05 & 0.05 & 0.05 \\
\hline
\end{tabular}

a,b,c,d,e :means in the same column bearing different superscripts are significantly different $(\mathrm{p} \leq 0.05) ; \mathrm{NS}=$ Non significant 
M.M. Beshara et al.

Table (7): Calcium and phosphorus in shell and tibia of Sinai hens fed diets containing different levels of anethol and vitamin $\mathrm{D}_{3}$

\begin{tabular}{|c|c|c|c|c|c|}
\hline \multicolumn{2}{|c|}{ Traits } & \multicolumn{2}{|c|}{ Egg shell } & \multicolumn{2}{|c|}{ Tibia } \\
\hline \multicolumn{2}{|c|}{ Treatments } & $\begin{array}{c}\text { Calcium } \\
\text { (mg/g) }\end{array}$ & $\begin{array}{c}\text { Phosphorus } \\
(\mathrm{mg} / \mathrm{g})\end{array}$ & $\begin{array}{c}\text { Calcium } \\
\text { (mg/g) }\end{array}$ & $\begin{array}{c}\text { Phosphorus } \\
\text { (mg/g) }\end{array}$ \\
\hline \multicolumn{6}{|c|}{ Source of trance-anethol } \\
\hline \multirow{5}{*}{\multicolumn{2}{|c|}{$\begin{array}{l}\mathrm{o} \\
4 \mathrm{~g} \text { anise } \\
180 \mathrm{mg} \text { oil } \\
\pm \mathrm{SE} \\
\mathrm{Sig}\end{array}$}} & $20.84^{\mathrm{a}}$ & 3.17 & 22.62 & $6.84^{\mathrm{b}}$ \\
\hline & & $19.78^{b}$ & 3.19 & 21.54 & $7.16^{\mathrm{a}}$ \\
\hline & & $17.56^{\mathrm{c}}$ & 3.13 & 20.96 & $6.66^{\mathrm{c}}$ \\
\hline & & 0.13 & 0.03 & 0.21 & 0.09 \\
\hline & & 0.05 & NS & NS & 0.05 \\
\hline \multicolumn{6}{|c|}{ Vitamin $\mathbf{D}_{3}$} \\
\hline \multirow{2}{*}{\multicolumn{2}{|c|}{$\begin{array}{l}2000 \\
2750\end{array}$}} & $20.64^{\mathrm{a}}$ & 3.15 & 22.50 & $6.84^{\mathrm{ab}}$ \\
\hline & & $18.62^{\mathrm{b}}$ & 3.20 & 22.14 & $6.62^{\mathrm{b}}$ \\
\hline \multicolumn{2}{|c|}{3500} & $18.92^{\mathrm{b}}$ & 3.14 & 20.48 & $7.09^{\mathrm{a}}$ \\
\hline \multicolumn{2}{|c|}{$\pm \mathrm{SE}$} & 0.13 & 0.03 & 0.21 & 0.09 \\
\hline \multicolumn{2}{|l|}{ Sig } & 0.05 & NS & NS & 0.05 \\
\hline \multicolumn{6}{|c|}{ Source of trance-anethol and vitamin D3 } \\
\hline \multirow{3}{*}{0} & 2000 & $21.52^{\mathrm{a}}$ & $3.21^{\mathrm{a}}$ & $21.78^{\mathrm{bc}}$ & $7.00^{\mathrm{ab}}$ \\
\hline & 2750 & $19.50^{\mathrm{b}}$ & $3.12^{\mathrm{ab}}$ & $24.64^{\mathrm{a}}$ & $6.53^{\mathrm{bc}}$ \\
\hline & 3500 & $21.52^{\mathrm{a}}$ & $3.18^{\mathrm{a}}$ & $21.42^{\mathrm{bc}}$ & $7.00^{\mathrm{ab}}$ \\
\hline \multirow{3}{*}{4} & 2000 & $21.24^{\mathrm{a}}$ & $3.12^{\mathrm{ab}}$ & $22.86^{\mathrm{ab}}$ & $7.13^{\mathrm{a}}$ \\
\hline & 2750 & $18.92^{\mathrm{b}}$ & $3.21^{\mathrm{a}}$ & $21.78^{b c}$ & $7.00^{\mathrm{ab}}$ \\
\hline & 3500 & $19.20^{\mathrm{b}}$ & $3.24^{\mathrm{a}}$ & $20.00^{c}$ & $7.33^{\mathrm{a}}$ \\
\hline \multirow{3}{*}{180} & 2000 & $19.20^{\mathrm{b}}$ & $3.12^{\mathrm{ab}}$ & $22.86^{\mathrm{ab}}$ & $6.40^{c}$ \\
\hline & 2750 & $17.46^{\mathrm{c}}$ & $3.27^{\mathrm{a}}$ & $20.00^{c}$ & $6.33^{c}$ \\
\hline & 3500 & $16.00^{\mathrm{d}}$ & $3.00^{\mathrm{b}}$ & $20.00^{c}$ & $6.93^{\mathrm{ab}}$ \\
\hline \multicolumn{2}{|l|}{$\pm \mathrm{SE}$} & 0.22 & 0.05 & 0.36 & 0.15 \\
\hline \multicolumn{2}{|l|}{ Sig } & 0.05 & 0.05 & 0.05 & 0.05 \\
\hline
\end{tabular}

a,b,c :means in the same column bearing different superscripts are significantly different $(\mathrm{p} \leq 0.05) ; \mathrm{NS}=$ Non significant 
Table (8): Economic efficiency of egg number as an effect to fed diets contained different levels of anethol and vitamin $\mathrm{D}_{3}$

\begin{tabular}{|c|c|c|c|c|c|c|c|c|c|}
\hline \multicolumn{2}{|c|}{ Trait } & \multicolumn{8}{|c|}{ Economic efficiency } \\
\hline \multicolumn{2}{|c|}{ Treatments } & $\begin{array}{c}\text { TFC/ } \\
\text { hen }^{1} \\
(L E)^{2}\end{array}$ & $\begin{array}{c}\text { FLC/ } \\
\mathbf{k g}^{3}\end{array}$ & $\begin{array}{l}\text { TFCC/ } \\
\text { hen }^{4}\end{array}$ & $\mathbf{E N}^{5}$ & $\begin{array}{c}\text { Price } \\
\text { of one } \\
\text { egg }\end{array}$ & $\begin{array}{l}\text { Total } \\
\text { return }\end{array}$ & $\begin{array}{l}\text { Net } \\
\text { return }\end{array}$ & EEF $^{6}$ \\
\hline \multicolumn{10}{|c|}{ Anethol } \\
\hline \multirow{3}{*}{\multicolumn{2}{|c|}{$\begin{array}{l}\mathrm{o} \\
4 \mathrm{~g} \text { anise } \\
180 \mathrm{mg} \text { oil }\end{array}$}} & 12.04 & 5.03 & 60.58 & 57.89 & 1.25 & 72.36 & 11.79 & $19.60^{\mathrm{ab}}$ \\
\hline & & 11.89 & 5.19 & 61.72 & 56.51 & 1.25 & 70.64 & 8.91 & $14.44^{\mathrm{b}}$ \\
\hline & & 12.01 & 5.09 & 61.16 & 60.91 & 1.25 & 76.13 & 14.98 & $24.50^{\mathrm{a}}$ \\
\hline \multicolumn{9}{|l|}{$\pm \mathrm{SE}$} & 2.40 \\
\hline \multicolumn{9}{|l|}{ Sig. } & 0.05 \\
\hline \multicolumn{10}{|c|}{ Vitamin $\mathrm{D}_{3}$} \\
\hline \multicolumn{2}{|c|}{2000} & 12.05 & 5.09 & 61.37 & 56.96 & 1.25 & 71.20 & 9.84 & $16.17^{\mathrm{b}}$ \\
\hline \multicolumn{2}{|c|}{2750} & 11.99 & 5.01 & 61.19 & 57.23 & 1.25 & 71.54 & 10.35 & $16.94^{\mathrm{b}}$ \\
\hline \multicolumn{2}{|l|}{3500} & 11.91 & 5.11 & 60.90 & 61.11 & 1.25 & 76.39 & 15.49 & $25.42^{\mathrm{a}}$ \\
\hline \multicolumn{9}{|l|}{$\pm \mathrm{SE}$} & 2.40 \\
\hline \multicolumn{9}{|l|}{ Sig. } & 0.05 \\
\hline \multicolumn{10}{|c|}{ Source of trans-anethol and vitamin D3 } \\
\hline \multirow{3}{*}{0} & 2000 & 12.09 & 5.02 & 60.68 & 56.81 & 1.25 & 71.01 & 10.33 & $17.09^{\mathrm{ab}}$ \\
\hline & 2700 & 12.21 & 5.03 & 61.42 & 57.56 & 1.25 & 71.94 & 10.53 & $17.19^{\mathrm{ab}}$ \\
\hline & 3500 & 11.83 & 5.04 & 59.63 & 59.31 & 1.25 & 74.13 & 14.51 & $24.51^{\mathrm{ab}}$ \\
\hline \multirow{3}{*}{4} & 2000 & 12.16 & 5.18 & 62.97 & 57.17 & 1.25 & 71.46 & 8.49 & $13.51^{\mathrm{b}}$ \\
\hline & 2700 & 11.84 & 5.19 & 61.46 & 55.47 & 1.25 & 69.34 & 7.88 & $12.74^{\mathrm{b}}$ \\
\hline & 3500 & 11.68 & 5.20 & 60.73 & 56.89 & 1.25 & 71.11 & 10.38 & $17.06^{\mathrm{ab}}$ \\
\hline \multirow{3}{*}{180} & 2000 & 11.89 & 5.08 & 60.45 & 56.92 & 1.25 & 71.15 & 10.70 & $17.92^{\mathrm{ab}}$ \\
\hline & 2750 & 11.92 & 5.09 & 60.70 & 58.67 & 1.25 & 73.33 & 12.64 & $20.88^{\mathrm{ab}}$ \\
\hline & 3500 & 12.22 & 5.10 & 62.33 & 67.14 & 1.25 & 83.92 & 21.59 & $34.69^{\mathrm{a}}$ \\
\hline \multirow{2}{*}{\multicolumn{9}{|c|}{$\begin{array}{l} \pm \text { SE } \\
\text { Sig. }\end{array}$}} & 4.16 \\
\hline & & & & & & & & & 0.05 \\
\hline
\end{tabular}

${ }_{1}$ TFC/hen=Total feed consumed/hen; ${ }^{2} \mathrm{LE}=$ Egyptian pound according to price at the experimental time; ${ }^{3} \mathrm{TFC} /$ hen $=$ Feed layer cost $/ \mathrm{Kg} ;{ }^{4} \mathrm{TFCC}=$ Total feed consumed cost; ${ }^{5} \mathrm{EN}=$ egg number; ${ }^{6} \mathrm{EEF}(\%)=$ economic efficiency $(\%)=($ Net return LE $/$ Total feed cost LE $) \times 100$. $a, b$ : means in the same row bearing different superscripts are significantly different $(p \leq 0.05)$ 


\section{REFERENCES}

Ali, M.N.; Hassan M.S. and Abd ElGhany, F.A. 2007. Effect of strain, type of natural antioxidant and sulphate ion on productive, physiological and hatching performance of native laying hens. International Journal of Poultry Science 6 (8): 539-554.

Al-Shammari, K.I.A. 2011. Effect of different concentrations supplementation with anise seeds (Pimpinella anisum L.) powder in drinking water in some productive indicators of broiler chickens. Journal of Babylon University/ Pure and App;ied Science 1(19) 200-208.

Ameenuddin, S.; Sunde, M. L.; DeLuca, H. F. and Cook, M. E., 1986. Excessive cholecalciferol in a layers diet: Decline in some aspects of reproductive performance and increased bone mineralisation of progeny. British Poultry Science 27:671-677.

Atencio, A.; Edwards, Jr. H. M.; Pesti, G. M. and Ware, G. O. 2006. The vitamin D3 requirement of broiler breeders. Poultry Science 85:674-692.

Bayram, I.; Cetingul, I. S. Akkaya, B. and Uyarlar, C. 2007. Effects of Aniseed (Pimpinella anisum L.), on egg production, quality, cholesterol levels, hatching results and the antibody values in blood of laying quails (Coturnix coturnix japonica). Archiva Zootechnica 10, 73-77.

Botsoglou, N.A., Yannakopoulos, A.L.; Fletouris, D.J.; Tserveni-Goussi, A.S. and Fortomaris, P.D. 1997. Effect of dietary thyme on the oxidative stability of egg yolk J. Agri. Food Chem., 45: 3712-3716.
Botsoglou, N.A.; Christaki, E.; Elorou-

Paneri, P.; Giannenas, I.; Papageorgiou, G. and Spais, A.B. 2004. The effect of a mixture of herbal essential oils or a-tocophery L acetate on performance parameters and oxidation of body lipid in broilers. S. Afr. J. anim. Sci., 34:52-61.

Browning, L.C. and Cowieson, A.J. 2015. Interactive effects of vitamin D 3 and strontium on performance, nutrient retention and bone mineral composition in laying hens. Journal of the science of food and Agriculture 94: 1389-1396.

Cabuk, M.; Alcicek, A.; Bozkurt, M. and Imre, N. 2003. Antimicrobial properties of the essential oils isolated from aromatic plants and using possibility as alternative feed additives. II National animal Nutrition Congress, 18-20 September, pp. 184187.

Castillo, L.; Tanaka, Y.; DeLuca, H.F. and Sunde, M.L. 1977.The stimulation of 25-hydroxyvitamin D31[alpha]-hydroxylase by estrogen. Archives of Biochemistry and Biophysics 179(1), 211-217.

Ciftci, M.; Güler, T.; Dalkiliç, B. and Ertas, O. N. 2005. The Effect of Anise Oil (Pimpinella anisum L.) On Broiler Performance. International Journal of Poultry Science 4 (11): 851855.

Choi, J.H.; Miles, R.D. and Harms, R.H. 1979. Blood phosphorus levels of laying hens at various time intervals after dosing with phosphoric acid. J. Nutr. 109, 1515-1518.

Christaki, E.V.; Bonoos, E.M. and Florou-Paneri, P.C. 2012. Use of anise seed and/or $\alpha$-tocopheryl acetate 
Cholecalciferol - Anethole - Egg production - Fertility - Hatchability

in laying Japanese quail diets. South African J. of Anm. Sci. 41 (2): 126133.

Combs, G. F. 1998. The Vitamins. 2nd ed. Acad. Press, San Diego, CA.

DeLuca, H. F. 2004. Overview of general physiology features and functions of vitamin D. American Journal of clinical Nutrition 80:16891696. Ding, B.A.; Pirone, A.; Lenzi, C.; Baglini, A. and Romboli, I. 2011. Effect of hen diet supplemented with $25-\mathrm{OH}-\mathrm{D}_{3}$ on the development of small intestine morphology of chicks. Journal of Animal and Feed Sciences, 20, 420-431

Duncan, D.B. 1955. Multiple ranges and multiple f-test, Biometries 11: 1-42.

Dusza, L.; Ciereszko, R.; Skarzyński, D.J.; Nogowski, L.; Opałka, M.; Kamińska, B.; Nynca, A.; Kraszewska, O.; Słomczyńska, M.; Woclawek-Potocka, I.; Korzekwa, A.; Pruszyńska-Oszmałek, E. and Szkudelska, K. 2006. Mechanism of phytoestrogens action in reproductive processes of mammals and birds. Reproductive biology. 6 Suppl 1, 151174.

Edwards, H. M. 1995. Factors influencing leg disorders in broilers. Pages 21-29 in: Proceedings of the Maryland Nutrition Conference. MD Feed Industry Council, Inc., University of Maryland College, College Park, MD.

Ertas, O.N.; Guler, T; Ciftci, M.; Dalkilic, B. and Simsek, G. 2005. The effect of essential oil mix derived from oregano, clove and anise on broiler performance. Int. J. Poult. Sci. 4 (11): 879-884.
Etches, R.J. 1996. Reproduction in poultry: Cab International ISBN 085198-738-9.

Feed Composition Tables For Animal and Poultry Feedstuffs Used In Egypt, 2001. Technical builetin No, 1, Center Lab Feed and Food; Ministry of Agriculture, Egypt.

Frost, T.J. and Roland, D.A. 1991. The influence of various calcium and phosphorus levels on tibia strength and eggshell quality of pullets during peak production. Poultry Science 70(40):963-969.

Fleming, R.H.; Mccormack, H.A.; Mcteri, L. and Whitehead, C.C. 2004. Incidence, pathology and prevention of keel bone deformities in the laying hen. Br. Poult. Sci. 45, 320330.

Fritts, C.A. and Waldroup, P.W. 2003. Effect of source and level of vitamin D on live performance and bone development in growing broilers. J. Appl. Poultry Res. 12, 45-52

Gulcin, I.; Oktay, M.; Kirecci, E. and Irfan Kufrevioglu, O. 2003.Screening of antioxidant and antimicrobial activities of anise (Pimpinella anisum L.) seed extract. Food Chem., 83: 371382.

HeeJeong, Y.; Noh-JaeWuk, Youn, H.J. and Noh, J.W. 2001. Screening of the anticoccidial effects of herb extracts against Eimeria tenella. Veterinary-Parasitology 96 4: 257263.

Kammer, D.M.; Moreng, R.E. Muller, H.D. and Hobbs, H.W. 1972. Turkey semen evaluation for fertility prediction. Poult.Sci.51:77-82.

Mattila, P.; Lenikoinen, K.; Kuskinen, T. and Puronen, V. 1999. 
M.M. Beshara et al.

Cholecalciferol and 25-

hydroxycholecalciferol content of chicken egg yolk as affected by the cholecalciferol content of feed. J. Agric. Food Chem. 47:4089-4092.

Mattila, P., Valaja, J.; Rossow, L. Venalainen, E. and Tupasela, T. 2004. Effect of vitamin D2- and D3enriched diets on egg vitamin D content, production, and bird condition during an entire production period. Poult. Sci. 83:433-440.

NRC. 1994. Nutrient Requirements of Poultry. National Academy Press, Washington, DC. Park, S. W., H. J. Namkung, H. J. Ahn, and I. K. Paik. 2005. Enrichment of vitamins $D_{3}, K$ and iron in eggs of laying hens. Asian-australas. J. Anim. Sci. 18:226229.

Nascimento, G.R.; Murakami, A.E.; Guerra; F.A.Q.M.; Ospinas-Rojas, I.C. Ferreira, M.F.Z. and Fanhani, J.C. 2014. Effect of different vitamin $\mathrm{D}$ sources and calcium levels in the diet of layers in the second laying cycle. Brazilian Journal of Poultry Science 16 (2): 37-42

Ni, Y.; Zhu, Q.; Zhou, Z.; Grossmann, R.; Chen, J. and Zhao, R. 2007. Effect of Dietary Daidzein on Egg Production, Shell Quality, and Gene Expression of ER- $\alpha$, GH-R, and IGFIR in Shell Glands of Laying Hens. Journal of Agricultural and Food Chemistry 55(17), 6997-7001.

Park, S. W.; Namkung, H. J.; Ahn, H. J. and Paik, I. K. 2005. Enrichment of vitamins D3, $\mathrm{K}$ and iron in eggs of laying hens. Asian-australas. J. Anim. Sci. 18:226-229.

Persia , M.E.; Higgins, M.; Wang, T.; Trample, D.; and Bobeck, E. A.
2013. Effects of long-term supplementation of laying hens with high concentrations of cholecalciferol on performance and egg quality. Poultry Science 92 :2930-2937.

Plaimast, H.; Kijparkorns and Ittitanawong, P. 2015. Effects of Vitamin D3 and Calcium on Productive Performance, Egg quality and Vitamin D3 Content in Egg of Second Production Cycle Hens. Thai J Vet Med. 2015. 45(2): 189-195.

Scott, M. L.; Nesheim, M. C. and Young, R. J. 1982. Nutrition of the Chicken. 3rd ed. M. L. Scott and Associates, Ithaca, NY. Ross Breeders. 2000. Ross Feeding Program Summary. 2000. Ross Breeders, Inc., Huntsville, AL.

Sandilands, V.; Moinard, C. and Sparks, N.H.C. 2009. Providing laying hens with perches: fulfilling behavioural needs but causing injury? Br. Poultry Science 50, 395-406.

Simsek, U.G.; Guler, T.; Çiftçi, M., Ertas, O.N. and Dalkilic, B. 2005. Esans yag karisiminin (kekik, karanfil ve anason) broylerlerde canlt agirlik, karkas ve etlerin duyusal özellikleri üzerine etkisi. YYÜ Vet Fak Derg .,16 (2): $1-5$.

Speake, B.K.; Murray, A.M.B. and Noble, R.C. 1998. Transport and transformation of yolk lipids during development of the avian embryo. Progress in Lipid Res., 37: 1-32.

Soliman, K.M. and Badea, R.I. 2002. Effect of oil extracted from some medicinal plants on different mycotoxigenic fungi. Food Chem. Toxicol., 40: 1669-1675.

Soltam, M.A.; Shwita, R.S. and ElKatcha, M.I. 2008. Effect o dietary 
Cholecalciferol - Anethole - Egg production - Fertility - Hatchability

anise seeds supplementation on growth performance, immune response, carcass traits and some blood parameters of broiler chickens. International Journal of Poultry Science 7 (11): 1078-1088.

SPSS. 2008. SPSS User's Guide Statistics. Ver. 17. Copyright SPSS Inc., USA.

Suda, T.; Ueno, Y.; Fujii, K. and Shinki, T. 2002.Vitamin D and bone. Journal Cell Biochemical 88:259-66.

Surai, P.F. 1999a. Vitamin E in avian reproduction. Poult. Avian Biology Review, 10: 1-60.

Swiatkiewicz, S.; Arczewska-Wlosek, A., Bederska-Ljewska, D and Jozefiak, D. 2017. Efficacy of dietary vitamin $\mathrm{D}$ and its metabolites in poultry - review and implications of recent studies. World's Poultry science Association 73: 57-68.

Tabanca, N.; Bedir, E.; Kirimer, N.; Baser, K.H.; Khan, S.I.; Jacob, M.R. and Khan, I.A. 2003. Antimicrobial compounds from Pimpinella species growing in Turkey. Planta Medical, 69: 933-938.

Nascimento, G.D.; Murakami, A.E.; Ospinas-Rojas, I.C.; Ferreira, M.F. and Fanhani, J.C. 2014. Effect of different vitamin $\mathrm{D}$ sources and calcium levels in the diet of layers in the second laying cycle. Brazilian Journal of Poultry Science 16 (2) 3742.
Van Cromphaut, S.J.; Rummens, K.; Stockmans, I.; Van Herck, E.; Dijcks, F.A.; Ederveen, A.; Carmeliet, P.; Verhaeghe, J., Bouillon, R. and Carmeliet, G. 2003. Intestinal Calcium Transporter Genes Are Upregulated by Estrogens and the Reproductive Cycle Through Vitamin D Receptor-Independent Mechanisms. Journal of Bone and Mineral Research 18(10), 1725-1736.

Zhao, R.Q.; Zhou, Y.C.; Ni, Y.D.; Lu, L.Z.; Tao, Z.R.; Chen, W.H. and Chen, J. 2005. Effect of daidzein on egg-laying performance in Shaoxing duck breeders during different stages of the egg production cycle. British Poultry Science 46(2), 175-181. 


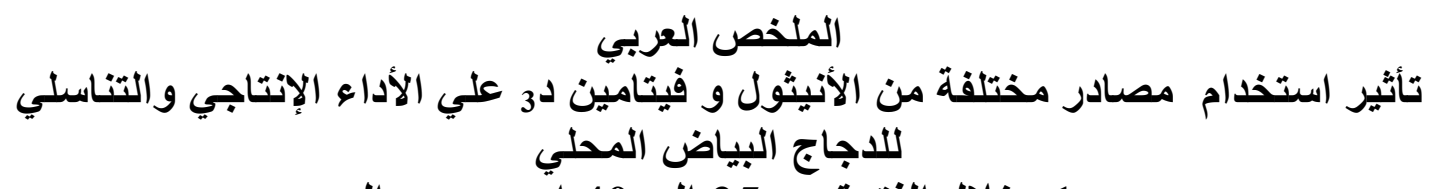

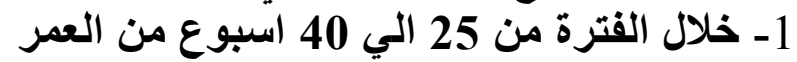

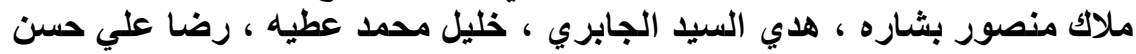

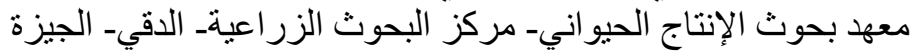

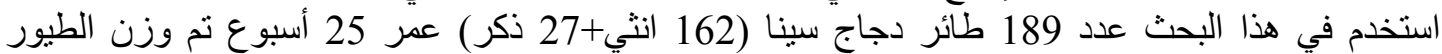

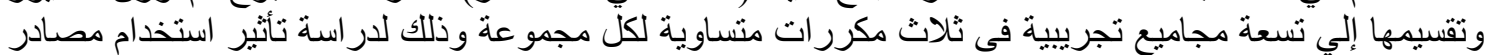

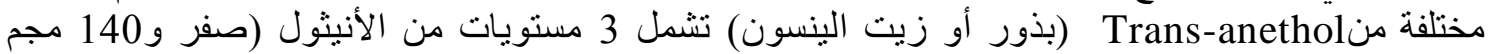

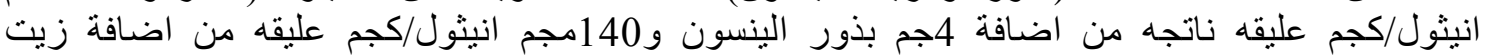

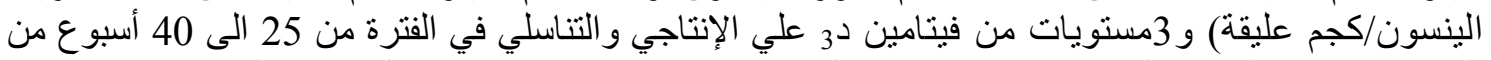

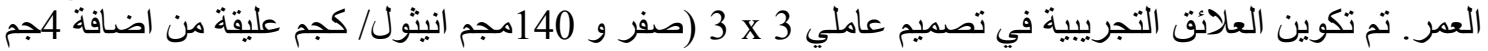

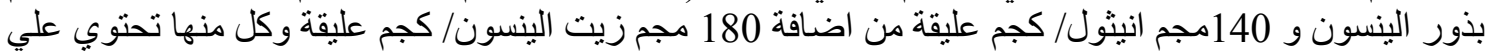

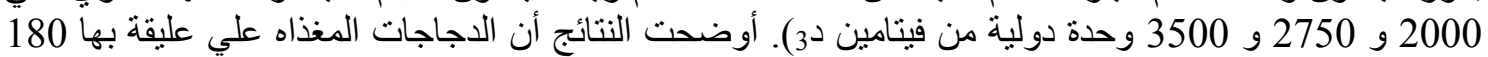

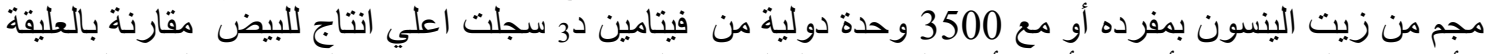

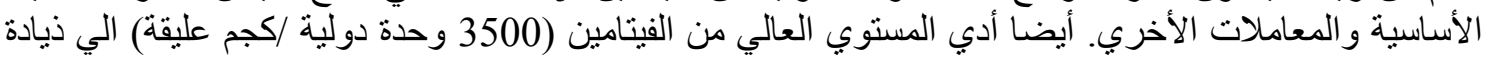

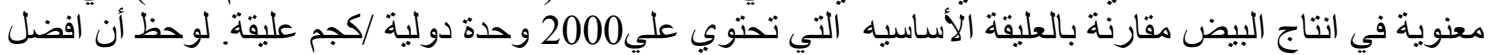

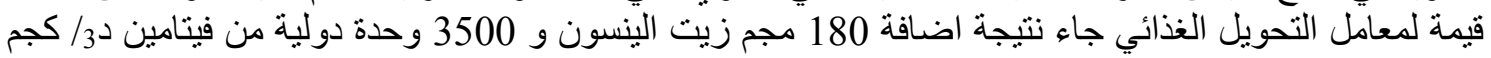

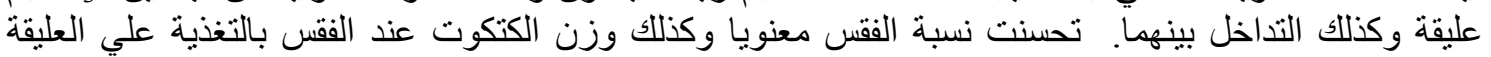

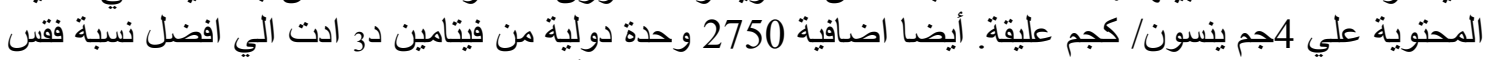

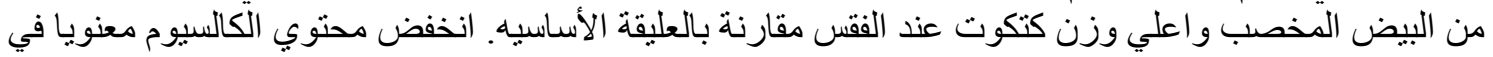

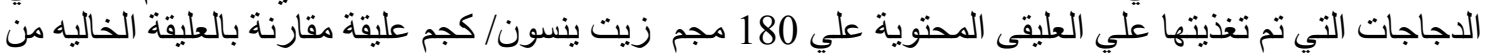

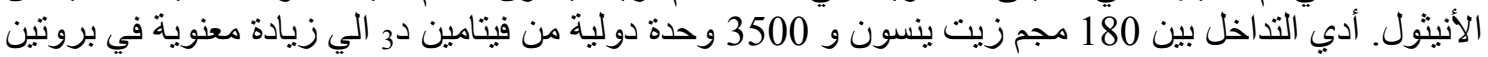

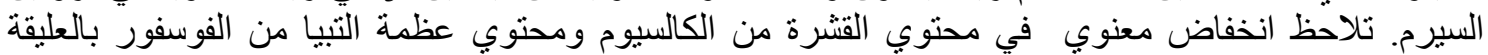

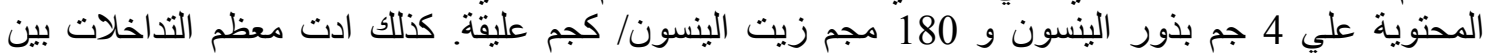

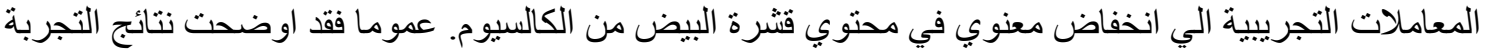

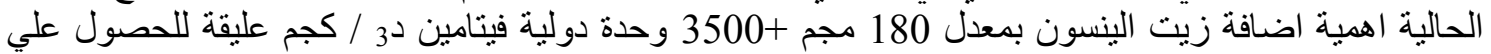

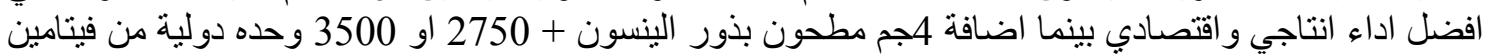
د3 ادي الي افضل اداء لنسبة الفقس وذلك خلال الفترة من 25 الي 40 اسبوع من العمر. 